(c) American Dairy Science Association, 2005.

\title{
Feeding Behavior Identifies Dairy Cows at Risk for Metritis
}

\author{
G. Urton, M. A. G. von Keyserlingk, and D. M. Weary \\ Animal Welfare Program, The University of British Columbia, Vancouver, BC, V6T 1Z4, Canada
}

\begin{abstract}
Dairy cows experience a high incidence of disease and metabolic disorders in the weeks immediately following calving, but early and accurate diagnosis remains a challenge. Cows suffering from metritis, one common disease following calving, exhibit reduced milk yield and reproductive performance. However, afflicted cows show few overt signs of illness and frequently go unnoticed in the absence of veterinary examination. To determine whether changes in feeding behavior could be used to identify animals at risk for metritis, attendance at the feed alley was monitored continuously for 26 Holstein cows during the transition period, beginning 2 wk before and ending 3 wk after calving. Every $3 \pm$ $1 \mathrm{~d}$, cows were examined for metritis based on rectal body temperature and condition of vaginal discharge. Over the 3 wk of observations after calving, $69 \%$ of cows showed some signs of metritis. These cows spent on average $22 \mathrm{~min} / \mathrm{d}$ less time at the feed alley during the transition period than did non-metritic cows. For every 10-min decrease in average daily feeding time, cows were twice as likely to be diagnosed with metritis. A threshold of $75 \mathrm{~min}$ of average daily feeding time was $89 \%$ sensitive and $62 \%$ specific for detection of acute metritis. In conclusion, reduced time at the feeder can be used to identify dairy cows at risk for metritis. More research is required to determine how soon before calving at-risk cows can be identified and whether these behavioral differences can also be used in the early diagnosis of other diseases or metabolic disorders.

(Key words: feeding behavior, dairy cow, metritis, transition)
\end{abstract}

Abbreviation key: $\mathbf{B T}=$ body temperature, $\mathbf{C I}_{\mathbf{9 5}}=$ $95 \%$ confidence interval, $\mathbf{V D}=$ vaginal discharge.

\section{INTRODUCTION}

Early identification or prediction of disease can minimize the duration of ill health and curb any resulting

Received January 5, 2005.

Accepted April 28, 2005.

Corresponding author: M. von Keyserlingk; e-mail: nina@ interchange.ubc.ca. economic losses. The transition period, defined by Grummer (1995) as beginning 3 wk before and ending 3 wk after calving, is a time when dairy cattle are at high risk for both metabolic and infectious disease (Drackley, 1999). Therefore, an improved ability to identify or predict disease in transition cows may be especially useful.

Veterinary examination is the gold standard of disease detection, but such exams are relatively infrequent on most dairy farms (commonly once every 2 wk postpartum), and many cases of disease may go unnoticed. Producers can use changes in milk production as well as urine or milk tests to monitor the health of their animals, but these tools have drawbacks. Milk production corresponds poorly with recognition of mild or subclinical infectious disease. In fact, Rajala-Shultz et al. (1999) found that cows with a mild fever produced more milk, on average, than did healthy cows. Frequent administration of tests on a herd-wide scale can also be costly and time-consuming. Moreover, no such tests are available for diagnosing inflammatory uterine disease (i.e., metritis or endometritis), one of the most common disorders after calving. Thus, a practical method for continuously monitoring transition cows to assess their health status or risk for disease would be beneficial.

Inflammatory uterine disease frequently occurs soon after calving and may severely compromise reproductive performance (Fourichon et al., 2000). Metritis and endometritis refer to the inflammation of the uterus and of its endometrial lining, respectively. Both diseases are a consequence of sustained infection of the uterus caused by pathogenic bacteria, such as Arcanobacterium pyogenes (LeBlanc et al., 2002). The distinction between these diseases is of little importance to this paper, so both conditions are referred to subsequently as metritis.

The incidence of metritis ranges from 10.1 to $65.5 \%$ in dairy cows (Borsberry and Dobson, 1989; Hirvonen et al., 1999). This wide range in incidence, in part, can be attributed to inconsistency in diagnosis and the lack of a clear definition of the disease in the literature (LeBlanc et al., 2002). Metritis may also form disease complexes with one or more other common transition period conditions including retained placenta, dystocia, abortion, left displaced abomasum, ketosis, milk fever, and ovarian cysts (Kaneene and Miller, 1995; Curtis et 
al., 1985). A lack of easily identifiable signs of metritis may also result in cases going unnoticed.

Much of the research on transition cows has focused on minimizing the incidence of disease in a preventive manner through improved nutrition. Despite great efforts in this area, the incidence of metritis remains high (Dohmen et al., 1995; Hirvonen et al., 1999). Currently, NRC (2001) recommends increasing the energy content of the precalving diet from $1.25 \mathrm{Mcal} / \mathrm{kg}$ of DM (recommended during the "far-off" dry period) to $1.62 \mathrm{Mcal} /$ $\mathrm{kg}$ of DM for the $3 \mathrm{wk}$ before calving. This strategy is thought to prepare the cow for the metabolic demands of early lactation and thereby minimize the need for body tissue mobilization. However, feed intake at this time may vary dramatically between animals because of individual differences in condition (Garnsworthy and Topps, 1982), social dominance (Friend and Polan, 1974), and likely other factors. Previous work (Marquardt et al., 1977; Zamet et al., 1979) has indicated that cows with lower feed intakes are more likely to be diagnosed with metabolic and infectious disease during transition. However, changes in feed intake must ultimately result from changes in feeding behavior. Moreover, feeding behavior has been shown to predict morbidity in feedlot steers (Sowell et al., 1998, 1999; Quimby et al., 2001) and may be similarly useful for prediction of disease in transition dairy cows. Therefore, the aim of this study was to test the hypothesis that cows exhibiting lower or reduced feeding behavior during the prepartum transition phase are at increased risk of developing metritis after calving.

\section{MATERIALS AND METHODS}

The experiment was conducted at The University of British Columbia's Dairy Education and Research Centre in Agassiz, BC. In this study, 6 Holstein heifers (BCS at the start of the study $=3.7 \pm 0.06 ; \overline{\mathrm{X}} \pm \mathrm{SD}$ ) and 20 Holstein cows (parity $=1$ to 3 and $\mathrm{BCS}=3.6 \pm 0.13$ at the start of the study) were housed in a freestall barn. Animals were monitored first in a precalving pen beginning $3 \mathrm{wk}$ before the expected date of calving and then in a postcalving pen until 3 wk after calving. Each of the pens contained 12 stalls deeply bedded with sand and $7.2 \mathrm{~m}$ of feed alley space. Stocking density of these pens was maintained at $100 \%$ (i.e., 12 cows per pen). When animals demonstrated signs of imminent calving (e.g., swollen vulva, mucus discharge from vulva, enlargement of the udder), they were moved to individual straw-bedded maternity pens. Within $24 \mathrm{~h}$ after calving, they were moved into the postcalving pen. Group size was kept constant, but group composition was dynamic, as animals were moved between pens as they progressed through the transition period.
Table 1. Ingredient composition of protein and mineral supplements fed to precalving and postcalving Holstein cattle.

\begin{tabular}{|c|c|c|}
\hline \multirow[b]{2}{*}{ Ingredient } & \multicolumn{2}{|c|}{ Supplement } \\
\hline & Precalving & Postcalving \\
\hline & $\longrightarrow$ & \\
\hline Corn distillers & 20.0 & \\
\hline Ground barley & 30.6 & \\
\hline Corn (finely ground) & & 48.1 \\
\hline Megalac $^{1}$ & & 1.2 \\
\hline Canola meal & 13.7 & 8.2 \\
\hline Soybean meal & 12.6 & 30.0 \\
\hline Alimet $^{3}$ & & 0.2 \\
\hline Amipro $^{3}$ & 10.0 & \\
\hline Urea & & 1.0 \\
\hline Dicalcium posphate & & 1.1 \\
\hline Calcium carbonate & & 3.9 \\
\hline Ground limestone & 3.4 & \\
\hline Yea-Sacc Farm Pak ${ }^{4}$ & 3.0 & 0.4 \\
\hline Magnesium oxide & 1.3 & 0.5 \\
\hline Blood meal & 1.0 & \\
\hline Molasses & 1.0 & \\
\hline Dicalcium phosphate & 0.2 & \\
\hline Vitamin/trace mineral premix & 3.2 & 1.5 \\
\hline Tallow & & 1.4 \\
\hline Salt & & 1.2 \\
\hline Sodium bicarbonate & & 0.3 \\
\hline
\end{tabular}

${ }^{1}$ Church and Dwight Co., Princeton, NJ.

${ }^{2}$ Novus International, Inc., St. Louis, MO.

${ }^{3}$ Unifeed Ltd., Chilliwack, BC, Canada.

${ }^{4}$ Alltech, Inc., Nicholasville, KY.

Animals were fed twice daily and were given ad libitum access to water. While housed in the maternity pens, animals were fed from a 1-m wide plastic food bin. Starting $3 \mathrm{wk}$ before expected calving date, cows were fed a TMR consisting of $25.8 \%$ alfalfa hay, $47.9 \%$ corn silage, and $26.3 \%$ protein and mineral supplement (Table 1) per cow on a DM basis (DM, 41.12\%; CP, 14.97\%; ADF, 20.02\%; and NDF, 33.47\%). After calving, cows were fed a TMR consisting of $7.2 \%$ grass hay, $1.8 \%$ alfalfa hay, $25.6 \%$ corn silage, $11.2 \%$ grass silage, $15.6 \%$ corn grain, and $38.6 \%$ protein and mineral supplement (Table 1) per cow on a DM basis (DM, 43.2\%; CP, 17.53\%; $\mathrm{ADF}, 16.59 \%$; and NDF 27.87\%).

\section{Feeding Behavior}

An electronic system (Growsafe Systems Ltd, Airdrie, $\mathrm{AB}$, Canada) was used to continuously monitor the presence of individual cows at the feed alley in the precalving and postcalving pens. This system, previously described and validated by DeVries et al. (2003a,b), scanned for the presence of each animal's transponder when within $0.5 \mathrm{~m}$ of the feed alley floor with a readrate of once every $4.4 \mathrm{~s}$ in the precalving pen and once every $5.8 \mathrm{~s}$ in the postcalving pen. The number of times that each transponder was read was multiplied by the 
corresponding read-rate to calculate the time each animal spent at the feed alley in a given period.

The day before calving, the day of calving and the 2 $d$ following calving $(d-1,0,1,2)$ were excluded from analysis because of the absence of a considerable number of animals from the trial pens on these days. The initiation of feeding behavior data collection varied as a result of the difference between projected and actual calving dates of the animals, but data from all animals were available from $\mathrm{d}-12$.

\section{Individual Animal Factors}

The BCS (Edmonson, 1989) of each cow was evaluated once every $4 \pm 1 \mathrm{~d}$ by a trained observer throughout the course of the study. Mean BCS over the precalving period was calculated from scores obtained from $d-17$ to -1 precalving, and mean BCS over the postcalving period was calculated from scores obtained from $\mathrm{d} 1$ to 21 postcalving. The change in BCS over the transition period was calculated as the difference between these 2 scores.

Individual milk weights were recorded for every cow at each milking for $21 \mathrm{~d}$ postcalving. Protein and fat content of milk was tested at $36 \pm 9 \mathrm{~d}$ postcalving (DIM \pm SD). Parity of each animal was recorded as either primiparous or multiparous after the experiment. The discrepancy between actual and predicted calving dates also resulted in a range (12 to $39 \mathrm{~d}$ ) of time spent on the precalving diet ( $22 \pm 6 \mathrm{~d}, \overline{\mathrm{X}} \pm \mathrm{SD})$, so this variable was also included in the analysis.

\section{Metritis Diagnosis}

Vaginal discharge (VD) was observed every $4 \pm 1 \mathrm{~d}$ after the morning milking (between 0830 and $1000 \mathrm{~h}$ ). Before palpation, the vulva of each cow was cleaned thoroughly with diluted Betadine solution (Purdue Pharma, Pickering, ON, Canada). Discharge was removed by a gloved hand from the opening of the cervix and then examined; the color and smell of the discharge and the relative amount of pus and mucus present were noted. Rectal body temperatures (BT) were measured daily immediately after the morning milking with a digital thermometer (GLA M525/550; GLA Agricultural Electronics, San Luis Obispo, CA).

Vaginal discharge was assigned to a category using the following scoring system adapted from Dohmen et al. (1995): no mucus, clear mucus, cloudy mucus, or mucus with flecks of pus $=1$; mucopurulent and foul smelling $=2$; purulent and foul smelling $=3$; and putrid (reddish brown, watery, foul smelling) $=4$. Fever was classified as $\mathrm{BT}>39.5^{\circ} \mathrm{C}$.

As there is disagreement in the literature concerning which diagnostic criteria constitute a case of metritis,
2 classifications were employed. Animals were classified as metritic if they showed a VD of $\geq 2$ plus fever (within $3 \mathrm{~d}$ before observation of $\mathrm{VD} \geq 2$ ) or acutely metritic if they showed a VD of 4 plus fever (within 3 $d$ before observation of $\mathrm{VD} \geq 2$ ).

\section{Statistical Analyses}

All statistical tests were performed (SAS, 1999) with the individual animal as the observational unit. Three different periods were designated for analysis: a precalving period ( $\mathrm{d}-9$ to -2 ), a postcalving period ( $\mathrm{d} 2$ to 19), and a trial period (precalving and postcalving periods combined). A preliminary period ( $\mathrm{d}-12$ to -10$)$ was also designated and tested as a covariate. Correlations were determined between each of these feeding behavior variables and the BCS variables (BCS and change in BCS). Effects of parity group on incidence of metritis and acute metritis were determined using a Fisher exact test. Differences in feeding behavior between classes of metritic and non-metritic cows were tested using $t$-tests. Multivariable logistic regression was performed using the LOGISTIC procedure in SAS (1999) to model the effects of feeding behavior and other factors (parity group, BCS, number of days on the precalving diet, and presence or absence of assisted calving) on the presence or absence of metritis and acute metritis. A manual backward stepwise procedure was used to remove the least significant variables sequentially until only variables with $P<0.1$ remained.

\section{RESULTS}

Examination of vaginal discharge over the $21 \mathrm{~d}$ after calving indicated that 18 cows (69\%) experienced some degree of pathological discharge (VD $\geq 2$ ). Specifically, putrid discharge was noted in $38 \%$ of cows, purulent and foul smelling discharge in $27 \%$ of cows, and mucopurulent discharge in $4 \%$ of cows (one animal). The number of days from calving to the first sign of pathological discharge (VD $\geq 2$ ) ranged from 3 to 15 DIM. The average BT $( \pm \mathrm{SD})$ of all cows over $21 \mathrm{~d}$ postcalving was $39.0 \pm 0.04^{\circ} \mathrm{C}$. The average BCS $( \pm \mathrm{SD})$ of all cows over the precalving and postcalving periods were $3.69 \pm 0.07$ and $3.47 \pm 0.07$, respectively. Although 4 of the 6 primiparous cows used in the study were diagnosed with metritis, the effect of parity was not significant for metritis $(P=0.371)$. However, there was a tendency for primiparous cows to be diagnosed with acute metritis $(P=$ 0.074).

On average, cattle spent less time at the feed alley over the precalving period (35\% or 32 min; Figure 1) and spent more time at the feed alley over the postcalving period (99\% or $46 \mathrm{~min}$ ). Mean BCS over the precalv- 


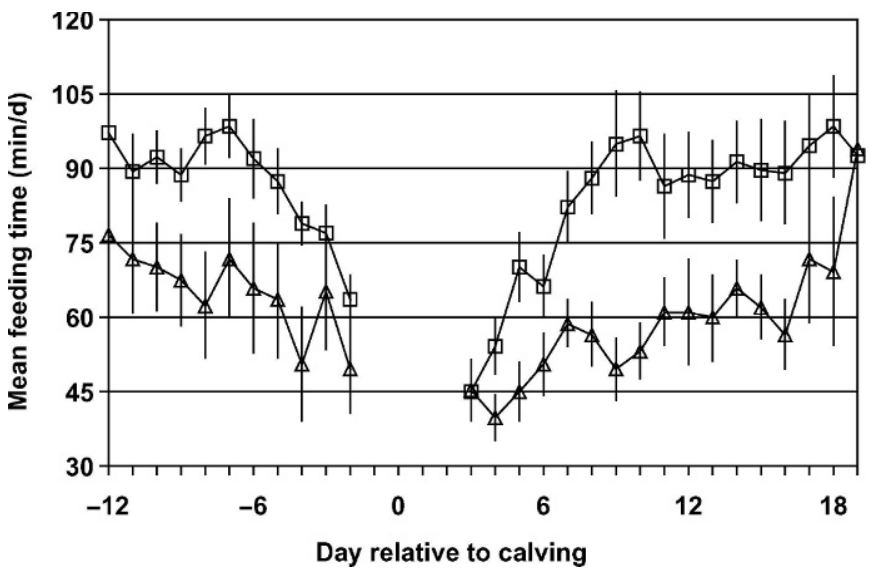

Figure 1. Daily mean feeding time ( $\mathrm{min} / \mathrm{d})$ of 9 Holstein cows with acute metritis $(\triangle)$ and 17 Holstein cows without acute metritis $(\square)$ $( \pm \mathrm{SE})$ from $12 \mathrm{~d}$ before calving until $19 \mathrm{~d}$ after calving.

ing period was negatively correlated with trial period feeding time $\left(\mathrm{R}^{2}=-0.43 ; P=0.027\right)$ but less so with precalving feeding time $\left(\mathrm{R}^{2}=-0.32 ; P=0.116\right)$. Change in BCS over transition was also negatively correlated with trial period feeding time $\left(\mathrm{R}^{2}=-0.40 ; P=0.043\right)$ and, to a lesser extent was negatively correlated with precalving feeding time $\left(\mathrm{R}^{2}=-0.37 ; P=0.062\right)$. No other animal factors were correlated to feeding behavior.

Cows diagnosed with either metritis or acute metritis spent less time feeding over the trial period than did non-metritic cows $(P<0.01$; Table 2$)$. These cows also spent significantly less time feeding over the post-calving period than did their healthy counterparts. However, only those cows diagnosed with acute metritis showed significantly $(P<0.05$; Table 2$)$ lower feeding time during the precalving period.

Logistic regression showed that trial period feeding time accounted for a significant amount of the variation in risk of metritis and acute metritis. Odds of metritis increased by 1.97 for every 10-min decrease in average daily trial period feeding time $\left[P_{\text {Wald }}=0.022 ; 95 \%\right.$ confidence interval $\left.\left(\mathrm{CI}_{95}\right)=1.97,4.02\right]$. Odds of acute metritis increased by 2.08 with every 10 -min decrease in average daily trial period feeding time $\left(P_{\text {Wald }}=0.013\right.$; $\left.\mathrm{CI}_{95}=1.24,4.32\right)$. None of the covariates were identified as significant for the metritis model, but for the acute metritis model, the effect of parity was significant $\left(P_{\text {Wald }}=0.038\right)$, with heifers showing a higher risk.

Feeding behavior would be most useful if measures precalving could identify animals at risk for metritis. Precalving feeding time was able to account for a significant proportion of variance in acute metritis $\left(P_{\text {Wald }}=\right.$ 0.018 ), with the odds of a positive diagnosis increasing by 1.57 for every 10 -min decrease in precalving feeding time. Parity was again the only significant covariate $\left(P_{\text {Wald }}=0.040 ; \mathrm{CI}_{95}=1.08,2.55\right)$ in the model.

Measures most useful for identifying animals at risk for metritis should be both sensitive and specific. The most useful threshold of daily precalving and trial period feeding time was 75 min, demonstrating a moderate to high sensitivity and specificity for detection of acute metritis and moderate sensitivity and specificity for detection of metritis (Figure 2).

\section{DISCUSSION}

The proportion of animals showing signs of metritis in the present study was similar to that reported by Dohmen et al. (1995; 80\%) and Hirvonen et al. (1999; $66 \%$ ), who used similar scoring criteria and a comparable day of diagnosis (14 DIM and 4 to 11 DIM, respectively). Le Blanc et al. (2002) conducted a validation of diagnostic criteria for metritis and found that presence of purulent (or worse) discharge after 20 DIM identifies endometritis associated with compromised reproductive function in the dairy cow. For this study, the definitions of metritis were not limited to include only those

Table 2. Mean and $\mathrm{SED}^{1}$ feeding times $(\mathrm{min} / \mathrm{d})$ for Holstein cows with and without metritis and acute metritis over 4 periods $^{2}$ relative to calving.

\begin{tabular}{llllllll}
\hline & \multicolumn{3}{c}{ Metritis } & & \multicolumn{3}{c}{ Acute metritis } \\
\cline { 2 - 3 } & $\begin{array}{l}\text { Present } \\
\text { Period }\end{array}$ & $\begin{array}{c}\text { Absent } \\
(\mathrm{n}=12)\end{array}$ & SED & & $\begin{array}{l}\text { Present } \\
(\mathrm{n}=9)\end{array}$ & $\begin{array}{l}\text { Absent } \\
(\mathrm{n}=17)\end{array}$ & SED \\
\hline Preliminary & 79.1 & 93.9 & 9.60 & 72.9 & 92.8 & $9.73^{*}$ \\
Trial & 65.4 & 87.6 & $7.41^{* *}$ & & 59.9 & 83.9 & $7.66^{* *}$ \\
Precalving & 68.9 & 87.0 & $3.99 \dagger$ & & 62.1 & 85.3 & $9.16^{*}$ \\
Postcalving & 73.5 & 87.9 & $8.35^{* *}$ & & 58.8 & 83.3 & $8.85^{*}$ \\
\hline
\end{tabular}

\footnotetext{
${ }^{1} \mathrm{SED}=$ standard error of the difference between mean feeding times.

${ }^{2}$ Preliminary period $=\mathrm{d}-12$ to $\mathrm{d}-10$, precalving period $=\mathrm{d}-12$ to $\mathrm{d}-2$, postcalving period $=\mathrm{d} 2$ to $\mathrm{d} 19$, and trial period $=$ precalving and postcalving periods combined.

$\dagger P \leq 0.10$.

$* P \leq 0.05$.

$* * P \leq 0.01$.
} 


\section{a. Acute metritis/Precalving period}

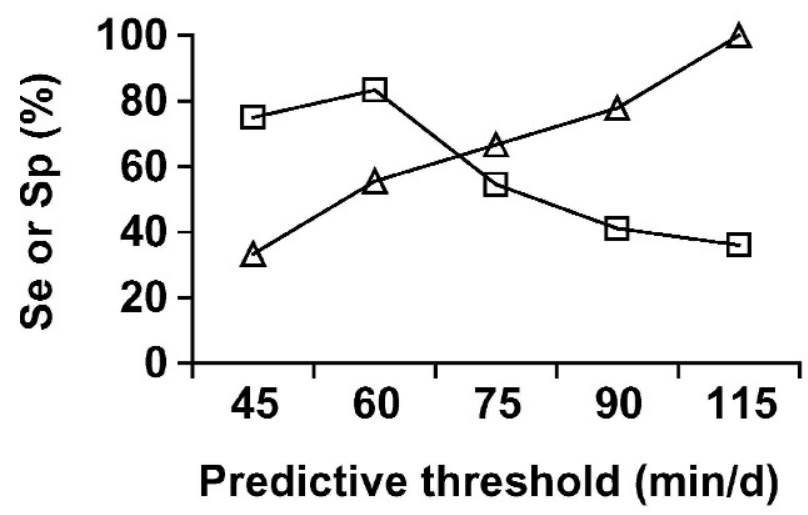

c. Metritis/Precalving period

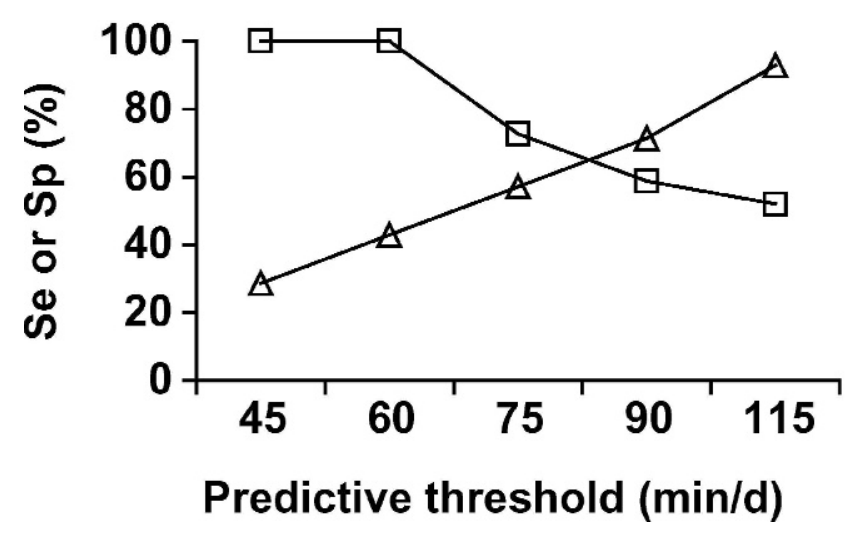

b. Acute metritis/trial period

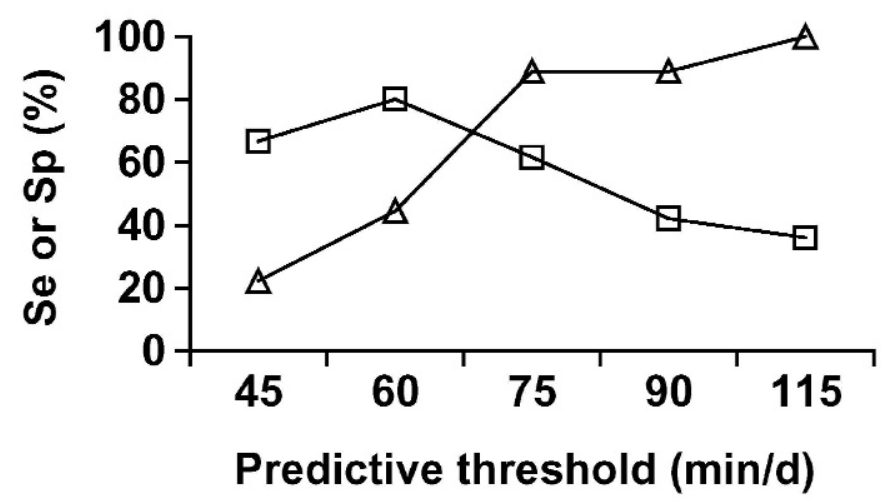

d. Metritis/trial period

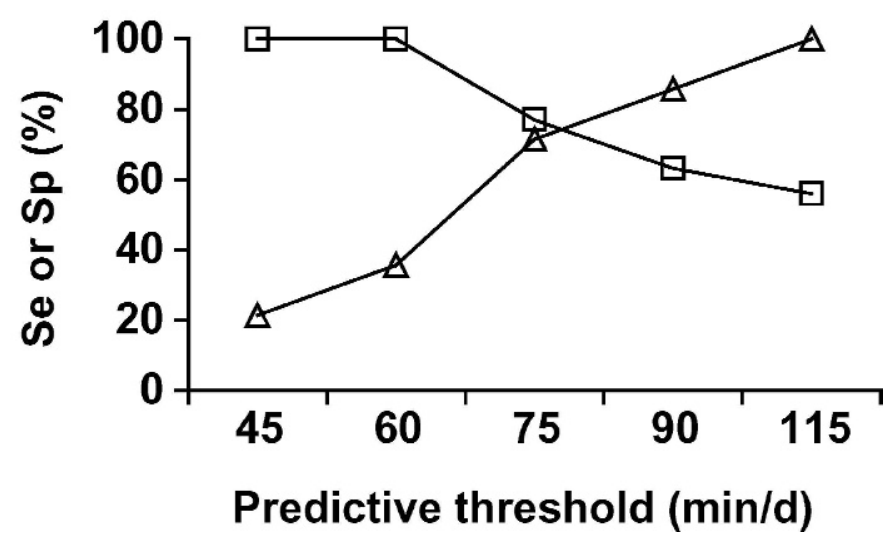

Figure 2. Sensitivity (Se; $\triangle$ ) and specificity $(\mathrm{Sp} ; \square)$ of predictive thresholds of mean daily feeding time (min $\mathrm{d} /$ ) in the precalving and trial periods to identify Holstein cows with metritis or acute metritis.

cases still present after $20 \mathrm{DIM}$; the interest was in metritis as a systemic infectious disease, not as a risk factor for compromised reproductive function.

Animals decreased their feeding time by $35 \%$ over the $2 \mathrm{wk}$ before calving and increased feeding times by 99\% over the $3 \mathrm{wk}$ after calving. This paper is the first to describe these changes in feeding times over this period, although others have observed a similar pattern in DMI. For example, Zamet et al. (1979) described an unspecified drop in DMI from 28 to $7 \mathrm{~d}$ precalving, followed by a $30 \%$ drop over the week before calving. Bertics et al. (1992) noted a $30 \%$ decline over the $3 \mathrm{wk}$ before calving with the majority of this drop occurring during the last week. Other researchers (Bertics et al., 1992; Vazquez-Anon et al., 1997) have also documented a doubling in DMI over the 3 wk after calving.
High BCS before calving has been identified as a factor contributing to the precalving decline in feed intake (Bines and Morant, 1983). Our results support this, indicating that over-conditioned cows generally eat less than thinner cows over the transition period. Our data also indicate that cows that lose body condition during transition spend less time feeding over this period. Factors thought to mediate the mobilization of accumulated body reserves and appetite during the transition period are discussed in depth by Ingvartsen et al. (Ingvartsen and Anderson, 2000; Ingvartsen and Boisclair, 2001; Ingvartsen et al., 2003).

To our knowledge this study is the first to show how disease relates to feeding behavior of dairy cows. Conventional feed intake monitoring systems restrict social interaction between animals while feeding, whereas the 
system that was used in this study allowed cows to interact normally at the feed bunk. Zamet et al. (1979) monitored the health and feed intake of free-stall housed cows over the transition period. Although these researchers noted a $21 \%$ lower DMI in metritic cows after calving (4 to $30 \mathrm{DIM}$ ), they failed to detect differences in DMI between these 2 groups before calving. Our work also showed that cows diagnosed with metritis had 29\% lower feeding times after calving, but we were also able to show a difference in precalving feeding times between healthy and metritic cows. This result suggests that feeding behavior can be a more sensitive indicator of disease than measures of individual feed intake can be. Indeed, the same behavior monitoring system used in the current experiment has been used to identify sick feedlot-housed beef steers successfully (Sowell et al., 1998, 1999; Quimby et al., 2001). Sowell et al. (1999) found that time spent feeding was lower (by as much as $35 \%$ over $4 \mathrm{~d}$ ) for steers demonstrating visible signs of bovine respiratory disease than for healthy animals. This figure is comparable with our overall difference in time spent feeding (29\%). Quimby et al. (2001) were able to use depressed feeding behavior to identify morbid steers $4.5 \mathrm{~d}$ earlier than were animal handlers. This study used cumulative sums analyses which requires a period of data stability to establish control parameters. This method would likely not be suitable for the relatively unstable feeding behavior characteristic of the transition period for dairy cows.

Our feeding behavior measures compare favorably in sensitivity and specificity for metritis detection with other tests used for disease detection in dairy cattle. For thresholds that were both suitably sensitive and specific ( $>60 \%$ ), our sensitivity ranged from 71 to $89 \%$, and our specificity ranged from 62 to $77 \%$. Similarly, suitable thresholds for on-farm milk and urine ketosis tests range in sensitivity from 76 to $80 \%$ and in specificity range from 76 to $93 \%$ (Geishauser et al., 1998). A more sophisticated laboratory test for ketosis using infrared milk analysis achieved high sensitivities of 79 to $100 \%$ and specificities of 85 to $100 \%$ (Heuer et al., 2001). In comparison, suitable SSC thresholds for mastitis detection were only 61 to $64 \%$ sensitive and 65 to $70 \%$ specific in one study (Sargeant et al., 2001).

Further work is needed to understand the factors that mediate the link between feeding behavior and diseases prevalent during transition, including the relationship between feeding behavior and feed intake. Other behavioural measures may also be helpful in improving our ability to identify animals at risk for metritis and other disease common at transition. Indeed, previous researchers have suggested that a variety of animal factors (e.g., feed intake, milk yield, walking activity) may be useful in early disease detection for transition cows (Bareille et al., 2003; Edwards and Tozer, 2004), but further empirical work is needed to test these ideas.

\section{ACKNOWLEDGMENTS}

The authors gratefully acknowledge the support of staff and students at the University of British Columbia's Dairy Education and Research Center and the insightful comments of members of the University of British Columbia's Animal Welfare Program at various stages of the project. We are especially grateful to Andreia Vieira for her help in a preliminary trial and in developing the criteria used in this study. We also thank Agriculture Canada for providing the feeding behavior monitoring equipment and Brian Upper and Raja Rajamahendran for the diagnostic training they provided. Financial support was provided by the Natural Sciences and Engineering Research Council of Canada, the Dairy Farmers of Canada, the British Columbia Dairy Foundation, the British Columbia Society for the Prevention of Cruelty to Animals, members of the British Columbia Veterinary Medical Association, and many others listed at www.agsci.ubc.ca/animalwelfare.

\section{REFERENCES}

Bareille, N., F. Beaudeau, S. Billon, A. Robert, and P. Faverdin. 2003. Effects of heath disorders on feed intake and milk production in dairy cows. Livest. Prod. Sci. 83:53-62.

Bertics, S. J., R. Grummer, C. Cadorniga-Valino, and E. E. Stoddard. 1992. Effect of pre-partum dry matter intake on liver triglyceride concentration and early lactation. J. Dairy Sci. 75:1914-1922.

Bines, J. A., and S. V. Morant. 1983. The effect of body condition on metabolic changes associated with intake of food by the cow. Br. J. Nutr. 50:81-89.

Borsberry, S., and H. Dobson. 1989. Periparturient diseases and their effect on reproductive performance in five dairy herds. Vet. Rec. 124:217-219.

Curtis, C. R., H. N. Erb, C. J. Sniffen, R. D. Smith, and D. S. Kronfield. 1985. Path analysis of dry period nutrition, postpartum metabolic and reproductive disorders, and mastitis in Holstein cows. J. Dairy Sci. 68:2347-2360.

DeVries, T. J., M. A. G. von Keyserlingk, and K. A. Beauchemin. 2003a. Short communication: Diurnal feeding pattern of lactating dairy cows. J. Dairy Sci. 86:4079-4082.

DeVries, T. J., M. A. G. von Keyserlingk, D. M. Weary, and K. A. Beauchemin. 2003b. Technical note: Validation of a system for monitoring feeding behaviour of dairy cows. J. Dairy Sci. 86:3571-3574.

Dohmen, M. J. W., J. A. C. M. Lohuis, G. Huszenicza, P. Nagy, and M. Gacs. 1995. The relationship between bacteriological and clinical findings in cows with subacute/chronic endometritis. Theriogenology 43:1379-1388.

Drackley, J. K. 1999. Biology of dairy cows during the transition period: The final frontier? J. Dairy Sci. 82:2259-2273.

Edmonson, A. J., I. J. Lean, L. D. Weaver, T. Farver, and G. Webster. 1989. A body condition scoring chart for Holstein dairy cows. J. Dairy Sci. 72:68-78.

Edwards, J. L., and P. R. Tozer. 2004. Using activity and milk yield as predictors of fresh cow disorders. J. Dairy Sci. 87:524-531.

Fourichon, C., H. Seegers, and X. Malher. 2000. Effect of disease on reproduction in the dairy cow: A meta-analysis. Theriogenology 53:1729-1759. 
Friend, T. H., and C. E. Polan. 1974. Social rank, feeding behavior, and free stall utilization by dairy cattle. J. Dairy Sci. 57:12141220 .

Garnsworthy, P. C., and J. H. Topps. 1982. The effect of body condition of dairy cows at calving on their food intake and performance when given complete diets. Anim. Prod. 35:113-119.

Geishauser, T., K. Leslie, D. Kelton, and T. Duffield. 1998. Evaluation of five cowside tests for use with milk to detect subclinical ketosis in dairy cows. J. Dairy Sci. 81:438-443.

Grummer, R. R. 1995. Impact of changes in organic nutrient metabolism on feeding the transition dairy cow. J. Anim. Sci. 73:2820-2833.

Heuer, C., H. J. Luinge, E. T. G. Lutz, Y. H. Schukken, J. H. van der Maas, H. Wilmink, and J. P. T. M. Noordhuizen. 2001. Determination of acetone in cow milk by Fourier transform infrared spectroscopy for the detection of subclinical ketosis. J. Dairy Sci. 84:575-582.

Hirvonen, J., G. Huszenicza, M. Kulcsàr, and S. Pyörälä. 1999. Acutephase response in dairy cattle with acute post-calving metritis. Theriogenology 51:1071-1083.

Ingvartsen, K. L., and J. B. Anderson. 2000. Integration of metabolism and intake regulation: A review focusing on periparturient animals. J. Dairy Sci. 83:1573-1597.

Ingvartsen, K. L., and Y. R. Boisclair. 2001. Leptin and the regulation of food intake, energy homeostasis and immunity with special focus on periparturient ruminants. Domest. Anim. Endocrinol. $21: 215-250$

Ingvartsen, K. L., R. J. Dewhurst, and N. C. Friggens. 2003. On the relationship between lactational performance and health: Is it yield or metabolic imbalance that cause production diseases in dairy cattle? A position paper. Livest. Prod. Sci. 83:277-308.

Kaneene, J. B., and R. Miller. 1995. Risk factors for metritis in Michigan dairy cattle using herd- and cow-based modeling approaches. Prev. Vet. Med. 23:183-200.

LeBlanc, S. J., T. F. Duffield, K. E. Leslie, K. G. Bateman, G. P. Keefe, J. S. Walton, and W. H. Johnson. 2002. Defining and diagnosing postpartum clinical endometritis and its impact on reproductive performance in dairy cows. J. Dairy Sci. 85:2223-2236.

Lewis, G. S. 1997. Uterine health and disorders. J. Dairy Sci. 80:984-994.

Marquardt, J. R., R. L. Horst, and N. A. Jorgensen. 1977. Effect of parity on dry matter intake at parturition in dairy cattle. J. Dairy Sci. 60:929-934.

National Research Council. 2001. Nutrient Requirements for Dairy Cattle. 7th rev. ed. Natl. Acad. Sci., Washington, DC.

Quimby, W. F., B. F. Sowell, J. G. P. Bowman, M. E. Branine, M. E. Hubbert, and H. W. Sherwood. 2001. Application of feeding behaviour to predict morbidity of newly received calves in a commercial feedlot. Can. J. Anim. Sci. 81:315-320.

Rajala-Schultz, P. J., Y. T. Gröhn, and C. E. McCulloch. 1999. Effects of milk fever, ketosis, and lameness on milk yield in dairy cows. J. Dairy. Sci. 82:288-294.

Sargeant, J. M., K. E. Leslie, J. E. Shirley, B. J. Pulkrabek, and G. H. Lim. 2001. Sensitivity and specificity of somatic cell count and California mastitis test for identifying intramammary infection in early lactation. J. Dairy Sci. 84:2018-2024.

SAS User's Guide. 1999. SAS Inst., Inc., Cary, NC.

Sowell, B. F., J. G. P. Bowman, M. E. Branine, and M. E. Hubbert. 1998. Radio frequency technology to measure feeding behavior and health of feedlot steers. Appl. Anim. Behav. Sci. 59:277-284.

Sowell, B. F., M. E. Branine, J. G. P. Bowman, M. E. Hubbert, H. E. Sherwood, and W. Quimby. 1999. Feeding and watering behavior of healthy and morbid steers in a commercial feedlot. J. Anim. Sci. 77:1105-1112.

Vazquez-Anon, M., S. J. Bertics, and R. R. Grummer. 1997. The effect of dietary energy source during mid to late lactation on liver triglyceride and lactation performance of dairy cows. J. Dairy Sci. 80:2504-2512

Zamet, C. N., V. F. Colenbrander, R. E., Erb, C. J. Callahan, B. P. Chew, and N. J. Moeller. 1979. Variables associated with pericalving traits in dairy cows. II. Interrelationships among disorders and their effects on intake of feed and on reproductive efficiency. Theriogenology 11:245-260. 